\title{
MASONRY CONSTRUCTION FOR EARTHQUAKE
}

\author{
by \\ I.L. Holmes $s^{x}$
}

\section{Texas Conference}

The International Conference on Masonry Structural Systems, held at Austin, Texas last December, was not particularly concerned with earthquake. But it showed up many points of design philosophy of intense interest to engineers concerned with earthquake design.

Conference chairman, Professor Neils Thompson summed up at the closing session by stating that masonry had come of age as a structural material; that this Conference marked the beginning of an era for structural masonry, comparable with that which besan for concrete at the beginning of the century. Masonry, which was the oldest building material, was now being given the same careful analytical attention that engineers had previously reserved for steel and concrete, and, more recently, timber and soils. Professor Thompson claimed for this Conference the title Wirst International Conference on Masonry Structural Systems", and this was readily granted by the 500 or 600 engineers present.

The rational analysis of masonry structures has been used, of course, by some engineers for many years. It was introduced into the New Zeal and design code (1) in July 1959. And this code followed trends in overseas codes such as the Uniform Building Code (2) of the U.S.A. and CP 111 of Britain. However codes alone do not establish a design methodology. Tests have to be made, designs made, and buildings themselves made. This International Conference was the fruit of the first ten years of such activity.

As the papers were presented it appeared almost that there were three schools of design philosophy. The majority of papers seemed to be concerned exclusively with unreinforced masonry. A smaller group of papers was concerned with lightly reinforced masonry. Only a very few papers described heavily reinforced masonry. Wach school seemed to be complete, and independent of the other. And in each school there were references to earthquake resistant design.

It might almost be said that each school represents a stage in the evolution of masonry structural design, at any rate for earthquake resistant structures. Design engineers in New Zeal and, for example, have in this process of evolution moved from unreinforced masonry, through lightly reinforced masonry, to heavily reinforced masonry.

The Conferencedid not leave time for any dialogue between the three schools to develop. Also pre-prints of individual papers were in short supply, and the Proceedings are not yet published. However, in what follows, an attempt will be made to evaluate the earthquake problem in masonry against the background of this first International Conference.

$x$ Partner in Holmes and Wood, Consulting Engineers,

Christchurch, New Zeal and. 


\section{Unreinforced masonry}

The oum ons thing aboutdesigners in unreinforced masonry is their persistence in refring the moteriel and the technique without adding reinforcirg. The result is a dungerously impressive structural capability.

Mortars are developcd to obtein higher bond and tension strengths. Walls are tested to get a closer refinement between allowable stress and lateral stability. Masonry units are test graded for compression strencth. Design calculations are refined to obtain a more accurate picture of stress distribution under load.

The result is higher and higher buildings and greater and greater confidence in their stability.

In Britain Curtin and Hendry (3) reported 6 storey residential halls with

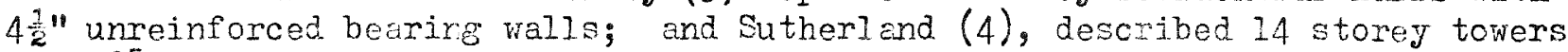
with $85 "$ "solid and 11 " cavity unreinforced bearing walls. For the latter "enbarrassing" tensile stresses due to wird were eliminated by a more careful analysis - by computer and model tests. There is a footnote: "Tarthquakes are not allowed for in Britair, but there is a move - and a good case can bo made for it - to include an arbitrary lateral stability force in our buildinc codes." hpart from earthquake, one is tempted to enquire what provision is made in these delicately tension-balanced builcirrs for explosion blast, either fron enemy action or from more innocent gas leaks:

From Switzerland Dr. Haller (5) reported a classic series of laboratory tests on unreinforced masonry, which "made possible the construction of buildirgs un to 18 storeys high and of 16 storey buildings with hearing walls measurire 5: 5 " in thickness." Dr. Haller includes in his papen a report on shear tests thich "have led to fractures similar in appearance to the cracks produced by earthquakes" and he concludes that "the shear strength is composed of the adhesion of the mortar to the masonry brick, the shear resistance of mortar plues and the friction forces which increase with risine compressive stress."

In the United States earthquake occurrence is more realistically appreciated than in Europe. The Uniform Buildine Code zones the whole of the United States for earthquake probability and only 6 States are shom as completely earthquake free. Even Texas has a Zone 2 section in the west. But in many parts of the United States urreinforced high-rise masonry buildings are being built. The refinements of design for these have been lergely promoted by the Structural Clay Products Institute (12) (13).

In a series of illustrated "Case Studies" issued by S.C.P.I. a number of high-rise unreinforced masonry buildings are described. These include the 9 storey Penn Plaza, Pittsburg, Pennsylvania; the 8 storey Heritage House, Canton, Ohio; and the 11 storey Housing for the Elderly, Rock Island, Illinois. Each of these unreinforced masonry buildings is in a Zone 1 seismic area. It is hard to believe that they have a great deal of earthquake resistance.

\section{Lightly reinforced masonry}

Lightly reinforced masonry has the characteristic that the Code minimum requirements of reinforcement are used; and more to boost the allowable masonry stresses than to add considerable tensile capacity. Tension stresses 
due to lateral loads of wind or earthquake are not high, and are offset by compression due to gravity loads. The effect of earthquake overload is not usually considered.

The Park Mayfair East apartment building, Denver, Colarado is 17 storeys and designed for seismic Zone 1. The paper (6) describing this building gives only limited information about the reinforcing. The walls are 11 in. brick composed of two wythes and a 3 in. grout core. Horizontal reinforcing is two $\frac{1}{4}$ smooth rods laid in the mortar joints each 5 courses. Vertical reinforcing is not described in the paper, but from one of the S.C.P.I. Case Studies it appears that $\frac{5}{8}$ " bars at $24^{\prime \prime}$ centres is used for all 17 storeys. It would seem that this building was designed for the limited Zone I coefficients of about 0.028 , or for wind loads. The lateral load tension forces undoubtedly were largely balanced by gravity load compressions, and the effect of earthquake loads greater than 0.028 were probably not calculated. "On April 10, 1967 an earthquake occurred with a reading of 5.0 on the Richter Scale and again on August 9, 1967 another shock with a reading of 5.5 on the Richter Scale shook the Denver area. Inspection of the building, following these tremors, did not show any damage or cracking in the structure." The question is whether this lightly reinforced, $165 \mathrm{ft}$. high, building would behave as well in a heavier earthquake.

A designer and pioneer of rational masonry design with confidence in the lightly reinforced wall to resist major earthquake forces is Walter I. Dickey, of Ios Angeles, California. In a philisophical paper (7) he records that "85\% of the masonry buildings that were reinforced and properly tied showed no damage in the major earthquake in Anchorage, Alaska." These included a series of concrete masonry warehouses designed by him for Elmendorf Air Force Base, with walls "30 ft. high with wide spacing of reinforcing - $4 \mathrm{ft}$. or more." He attributes the lack of damage to the short period and high damping of the masonry, combined with ductility provided by the reinforcing.

Support for the wide nominal spacing of reinforcing is quoted from a series of static and vibration tests on $20 \mathrm{ft}$. high panels (1I). As the result of these tests it is claimed that, in these panels, reinforcing functions as effectively at $8 \mathrm{ft}$. spacing as it does at $2 \mathrm{ft.}$, and that the panels effectively dissipate earthquake energy.

\section{Heavily reinforced masonry}

Design to the United States Zone 3 and the requirements of the 1967 edition of the Uniform Building Code (2) leads to what might be termed heavily reinforced masonry. Principal reinforcement, by section 2314 (k), must be at 24 " centres maximum, and reinforcing perpendicular to this, by section 2418 ( $f$ ), at 48" centres maximum. By'section 2417 (i), tensile stress due to earthquake forces can be reduced by only $50 \%$ of the stress due to dead load.

The design process is usefully summarised in a recent publication of the Concrete Masonry Association of California (14). In this summary a 10 storey motel is used as a design example.

A further paper (8) to the Texas Conference by Walter L. Dickey described a building conforming to the Uniform Building Code, and presumably to Zone 3. This is a 4 storey Naval Barracks at San Diego, California. Interior walls are 8 " concrete block reinforced vertically with $\frac{1}{2} "$ at 24 " and horizontally with $\frac{5}{8} "$ and $\frac{3}{4} "$ rods at floors and lintels. Exterior walls are 8 " brick, with two $3 "$ wythes and a $2^{\prime \prime}$ grout core, reinforced both ways with $\frac{1}{2} "$ at $24 "$ ". 
Design to the New Zealand code N.Z.S.S. 1900 (1) also leads to heavily reinforced masonry. The requirements of this code and the development of the code out of the history of masonry in New Zeal and are described in a paper (9) by the present author.

Unlike the United States zones, the zones in New Zealand represent relatively small differences in design load. For short period buildings Zones A, $B$ and $C$ have coefficients of $0.12,0.10$ and 0.08 respectively. Vertical reinforcing is required to be placed at not more than $40^{\prime \prime}$ centres, and horizontal reinforcing "where practicable" at $32^{\prime \prime}$ centres. In general, both vertical and horizontal reinforcerent in multi-storey buildings is placed at $16^{\prime \prime}$ to $32^{\prime \prime}$ centres.

\section{Earthquake survival}

We are beginning to learn that the rules that define the collapse of one building in an earthquake and the survival of another are not simple. It is not possible to make generalisations. Unreinforced masonry buildings have survived severe earthquakes; lightly reinforced masonry, as at Anchorage, has survived severe earthquakes. It does not seem sufficient to argue from example. The logic of the designer's malysis must ultimately be our guide.

In masonry as with concrete the concepts of natural period, of damping and of ductility must apply.

Many masonry buildings that have survived severe earthquakes have been special cases. The long low building of natural period less than 0.2 sec. probably receives less energy from the ground motion than buildings of 0.2 sec. to $0.6 \mathrm{sec}$. Also it will have considerable damping capacity. If it is well built, if the mortar is high quality, and if the various parts of the building are well tied together it can be expected to survive. But this does not make a case for generally designing buildings of unreinforced masonry.

\section{Zoning and overload}

A particular weakness of unreinforced or lightly reinforced masonry buildings is that there is limited reserve of strength against overload.

The concept of zoning should not result in a building being insufficiently strong to be able to survive a "major damage" earthquake. The zoning map is a map of seismic probability. The design coefficients associated with a particular zone reflect the probable damage that a given building in that zone will experience in its lifetime. The probability is related to the likely distribution, in space and time, of epicentres and earthquake magnitudes. However, whatever the probability, there always remains the possibility that a building will suffer a close epicentre and be severely damaged. It is important that in these circumstances it does not collapse.

An unreinforced or lightly reinforced building closely designed for Zone 1 coefficients cannot be expected to behave well in local intensities greater than about MM.VII. This means that subject to a nearby shallow earthquake of Magnitude 6 to $6 \frac{1}{2}$, giving epicentre intensities of M.XIII or IX, there would be severe damage, or even collapse. Sarthquakes of magnitude 6 to $6 \frac{1}{2}$ have a habit of popping up where least expected. There are about 100 of this magnitude recorded in the world every year. 
Unreinforced and lightly reinforced masonry buildings are frequently designed with the earthquake tensions of bending and shear balanced by compression due to gravity loads. This is particularly so for multi-storey buildings. In this case there is practically no overload reserve. As soon as the earthquake tension overbal ances the gravity compression the building will crack, and with a further increase in earthquake load collapse must follow.

The only security against overload is adequate tension reinforcing to give ductility into the overload range.

\section{Minimum reinforcement}

The contribution that reinforcing makes to the ductility of masonry has been demonstrated in a number of tests. Just how much reinforcing and how much ductility is needed is a matter that concerns the designer. It is an important problem because both reinforeing and the grout that surrounds it are expensive ingredients in the masonry wall.

The series of raking tests reported by Dr. Scrivener (10) were an attempt to find the relationship between reinforcing and ductility. They were relatively simple tests but the results were informative. For the $8 \mathrm{ft}$. $8 \mathrm{ft}$. panels tested, with various arrangements of reinforcement, the following general conclusions were drawn. The percentage of reinforcement was more important than the arrangement of reinforcement; al though distributed reinforcement controlled early cracking better than peripheral reinforcement. Nevertheless there was a point where further increases in reinforcement did not increase the failure strength of the panel. This was at $0.3 \%$ of the gross cross section.

It would appear from this and other evidence that a relatively small amount of reinforcing considerably increases strength and ductility. This supports the ovservations of Walter L. Dickey (7) (1I). Therefore all masonry that is likely to be an earthquake hazard should be reinforced. This applies to veneers, partitions and panels, unless they can only fall to the level of their own base. The logical reinforcement for these, particularly if they are in running bond, is vertical bars at uniform centres. In veneers there is no reason why deformed bars should not be galvanised for added weather protection. For design of the reinforcement and anchorages the coefficients of Table 23-I of the Uniform Building Code seem appropriate.

Peripheral reinforcement is so effective in protecting a small building against earthquake that "partial" reinforcement should be used for the main walls of all small buildings. This is discussed in more detail in the author's previous paper (9). "Partial" reinforcing is adequately described in the Uniform Building Code, section $2417(\mathrm{k})$.

Multi-storey buildings can only be adequately reinforced after a full design analysis. This will take into account the interaction of all the structural elements according to their relative stiffnesses. Walls may act as simple cantilevers from ground level, or they may have a framing action through floor slabs or lintels with adjacent walls. It is important to approximate as closely as possible to an exact analysis of structural behaviour. Reinforcement can then be located where it is most effective to achieve ductility.

As a multi-storey masonry building is particularly susceptible to overload collapse; it would seem inadvisable to design it for any load less than the coefficients of Zone 3. In New Zeal and the appropriate coefficients would be those of Zone A. 
It is inevitable that a multi-storey masonry building designed under these conditions would be heavily reinforced. Bars horizontally and vertically should be at not more than 24" centres and not less than $\frac{1}{2}$ " diameter, with heavier bars at wall ends as required by the analysis.

Finally the multi-storey building should be checked for overload. For the desicn coefficients of Zone 3, the real earthquake forces on the damped structure have been reduced by a factor of 3 or 4 . The reduction is justified by the fact that the ultimate capacity of the building is in a range somewhat beyond the design level of elastic working stresses plus 33\%. It is important to check that the ultimate capacity is not less than an appropriate factor times the design load.

In reinforced masonry the satisfactory behaviour of the structure beyond the design level is probably best investigated by checking ultimate capacity using the concept of limiting strains.

\section{Conclusions}

The International Conference in Texas demonstrated that masonry can now be accepted as a high quality structural material, capable of exact analysis and amenable to close control. As such its behaviour in an earthquake can be reassessed. The former prejudices against masonry for earthquake resisting buildings no longer apply.

In making a re-assessment it is important to realise the significance of earthquake zoning. Zones are based on earthquake probability in terms of intensity and of frequency at a riven place. Intensity is related to distance from the epicentre as well as to magnitude. In using low design coefficients the possibility of a chance "direct hit" should not be overlooked.

Unreinforced or lightly reinforced masonry, carefully designed and built, will behave well in a zone of low seismic probability provided that it is not subject to a felt intensity greater than about MM.VI. But if a shallow earthquake of Magnitude 6 occurred close to the building then it would be severely damaged or even collapse. This is a possibility that cannot be ignored. It is more important for multi-storey buildings than for buildings of one storey.

Muli-storey buildings cannot be considered adequately designed, whatever the earthqualie probability zone, if they have not been checked for a major earthquake shock. This invariably means an assessment of damping and ductility in the structure. Both these qualities depend on adequate reinforcing.

How much, or what kind of reinforcing is adequate, is the current problem for designers. The requirements are likely to be quite different for low buildings than for multi-storey buildings. The requirements are also likely to vary according to the resisting system of the building.

Quantitatively, reinforcement requirements in masonry will differ from those in concrete because of the difference in compression strength and in other properties.

The author considers that unreinforced masonry should be used only rarely. It should not be used for veneers above one storey and it should not be used for partitions or panels that can fall below their own level. Veneers, partitions and panels are adequately reinforced if reinforced in one direction only. They should be tied to the building with anchorages to resist $2.0 \mathrm{~g}$. 
Small buildings are adequately reinforced with partial reinforcement, generally as defined in the Uniform Building Code, 2417 ( $\mathrm{k}$ ).

Multi-storey buildings should be designed to a carefully selected earthquake load, which probably should not be less than that appropriate to Zone 3 in the United States or Zone A in New Zealand. The design should follow all the usual considerations of a careful elastic analysis (14) and then it should be tested for the effects of overload on the design earthquake force.

Unreinforced or lightly reinforced masonry should not be used for multistorey buildings in earthquake areas, whatever the zoning probability. It is doubtful if unreinforced masonry should be used for multi-storey buildings even in earthqualke free areas.

\section{References}

(1) Standards Association of New Zealand, N.Z.S.S. 1900 : Model Building Bylaw.

(2) International Conference of Building Officials, "Uniform Building Code" 1967 Edition. Pasadena, California.

(3) CURTIN, W.G. and HENDRY, A.W. "The design and construction of slender wall brickwork buildings" International Conference on Masonry Structural Systems, Austin, Texas, November 1967.

(4) SUTHRRLAND, R.J.M. "A design engineer's approach to masonry construction" Ibid.

(5) HALIRR, P. "Load capacity of brick masonry" Ibid.

(6) HANSON, George C. "Park Mayfair East" Ibid.

(7) DICKEY, Walter I. "Reinforced masonry revisited, or Ten years later" Ibid.

(8) DICKYY, Walter L. "Seismic resistant naval barracks" Ibid.

(9) HOLMES, I.L. "Masonry building in high intensity seismic zones" Ibid.

(10) SCRIVENER, J. "Static raking tests on concrete masonry walls" Ibid.

(11) MACKINTOSH, A. and DICKEY, W.L. "Effective width in floxure" Test Report, Concrete Masonry Association, Califormia.

(12) Structural Clay Products Institute, "Recommended building code requirements" May 1968, Washington, D.C.

(13) Structural Clay Products Institute, "Proceedings of the First National Brick and Tile Bearing Wall Conference" May 1965, Pittsburgh, Penn.

(14) Concrete Masonry Association of California "Reinforced load bearing concrete block walls for multi-storey construction" 1967, Los Angeles, California. 